\title{
Cyclic AMP-induced expression of steroidogenic acute regulatory protein is dependent upon phosphoprotein phosphatase activities
}

\section{P M Jones, S B Sayed, S J Persaud, C J Burns, S Gyles and B J Whitehouse}

Endocrinology and Reproduction Research Group, School of Biomedical Sciences, King's College London, New Hunt's House, Guy's Campus, London SE1 1UL, UK

(Requests for offprints should be addressed to P M Jones; Email peter.jones@kcl.ac.uk)

\begin{abstract}
In addition to the well-documented role of protein kinases in the regulation of steroid production, phosphoprotein phosphatase (PP) activity is required for steroidogenesis. In the present study, we have used the mouse Y1 adrenocortical cell line to identify the site of action of PPs on steroid production by measuring the effects of PP inhibition on the expression of the steroidogenic acute regulatory (StAR) protein and on steroid production. Forskolin-induced activation of cyclic AMPdependent protein kinase (PKA) enhanced steroidogenesis and this was accompanied by an increased
\end{abstract}

expression of StAR protein. Both steroidogenesis and StAR protein expression were inhibited by two structurally dissimilar inhibitors of PP1 and PP2A activities, okadaic acid and calyculin A. These results suggest that inhibition of $\mathrm{PP} 1$ and $\mathrm{PP} 2 \mathrm{~A}$ inhibits steroid production by preventing the expression of the StAR protein, implicating PP1/2A dephosphorylation reactions as important regulators of stimulus-dependent StAR protein expression, and thus of steroidogenesis.

Fournal of Molecular Endocrinology (2000) 24, 233-239

\section{INTRODUCTION}

Agonist-dependent activation of the cyclic AMPdependent protein kinase (PKA), and the consequent phosphorylation of cellular proteins is a critical stage in the stimulation of steroid production (see Orme-Johnson 1990, Schimmer 1995), although the identities and functions of the PKA substrates are still uncertain (Stocco \& Clark 1996, Kim et al. 1997, Papadopoulos et al. 1997). PKA-mediated events are rapidly reversible through the actions of phosphoprotein phosphatases (PPs; Cohen 1989), and we have demonstrated that at least three of these enzymes, PP1, PP2A and $\mathrm{PP} 2 \mathrm{~B}$, are expressed in primary luteal and adrenal cells (Ford et al. 1996, Sayed et al. 1997). PP1 and PP2A activities appear to be obligatory for stimulated steroid production since inhibitors of these enzymes have profound inhibitory effects on PKA-dependent steroidogenesis (Azhar et al. 1992, 1994, Abayasekara et al. 1996, Ford et al. 1996, Sayed et al. 1997). This action of PP inhibitors is before the delivery of cholesterol to the inner mitochondrial membrane since there was no inhibition of steroid production from 22R-hydroxy cholesterol (22ROHC), which freely crosses the aqueous space between outer and inner mitochondrial membranes (Abayasekara et al. 1996, Sayed et al. 1997).

Delivery of cholesterol to the inner mitochondrial membrane is the rate-limiting step in steroidogenesis and evidence is accumulating that mitochondrial cholesterol transport is dependent on the expression of the steroidogenic acute regulatory (StAR) protein (Clark et al. 1994, Stocco \& Clark 1996, Stocco 1997, 1998). For example, expression is restricted to steroidogenic tissues (Clark et al. 1995a) and correlates well with changes in steroid production (Nishikawa et al. 1996, Liu \& Stocco 1997, Ramnath et al. 1997, Stocco 1997), experimental over-expression of StAR protein increases steroid production (Clark et al. 1994) and the reduced steroid production in congenital lipoid adrenal hyperplasia has been attributed to mutations in the 
StAR protein gene (Lin et al. 1995). Furthermore, a number of studies have shown that pharmacological or receptor-operated activation of PKA stimulates steroid production by increased expression of the StAR protein (Clark et al. 1994, Liu et al. 1996, Balasubramanian et al. 1997, Pescador et al. 1996). In the present study, we have investigated whether StAR protein expression is also the site of regulation of steroidogenesis by PP1 and PP2A.

\section{MATERIALS AND METHODS}

\section{Materials}

Tissue culture reagents and plastics were from Gibco BRL (Paisley, Strathclyde, UK). Calyculin A (Cal A) and okadaic acid (OA) were from Calbiochem (Nottingham, Notts, UK). Polyclonal antisera against PP1 and PP2A, and a monoclonal antibody against PP2B were from TCS Biologicals (Botolph-Claydon, Bucks, UK). A polyclonal antiserum against StAR protein was a kind gift from Professor Douglas Stocco (Texas-Tech University, TX, USA). Horseradish peroxidase-coupled goat anti-rabbit immunoglobulin $\mathrm{G}(\mathrm{IgG})$ and goat anti-mouse $\mathrm{IgG}$ were from Dako A/S (Glostrup, Denmark). Enhanced chemiluminescence (ECL) reagents, Hyperfilm and 1,2,6,7 $\left[{ }^{3} \mathrm{H}\right]$ progesterone for use in radioimmunoassay (RIA) were from Amersham International plc (Amersham, Bucks, UK). All other biochemicals were from the Sigma Chemical Company Ltd (Poole, Dorset, UK).

\section{Cells}

Mouse adrenocortical Y1 cells were obtained from the European Collection of Cell Cultures (Salisbury, Wiltshire, UK), and maintained in Dulbecco's modified Eagle's medium (DMEM) supplemented with $100 \mu \mathrm{g} / \mathrm{ml}$ streptomycin, $100 \mathrm{U} / \mathrm{ml}$ penicillin and $10 \%(\mathrm{v} / \mathrm{v})$ foetal bovine serum in a humidified atmosphere of $5 \% \mathrm{CO}_{2}$. Cell viability was assessed by microscopic assessment of Trypan blue exclusion after incubation in $0.1 \%(\mathrm{w} / \mathrm{v})$ Trypan blue in DMEM for $15 \mathrm{~min}$ at $37^{\circ} \mathrm{C}$. Mitochondrial function was assessed using a tetrazolium assay to measure dehydrogenase activities, in which cells were incubated in the presence of 3(4,5,-dimethylthiazol-2-yl)-2-5-diphenytetrazolium bromide (MTT, $0.5 \mathrm{mg} / \mathrm{ml}$ ). The reaction was terminated by the addition of acidified propanol, and the conversion of MTT to formazan was quantified by measuring the absorbance at $570 \mathrm{~nm}$.

\section{Steroid production}

Steroid production by monolayers of $\mathrm{Y} 1$ cells seeded in 96 -well microculture plates at a density of $2 \times 10^{5}$ cells per well was assessed as described previously for primary adrenal cells (Sayed et al. 1997). Y1 cells

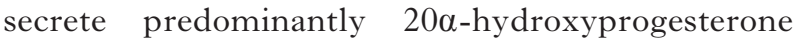
(Schimmer 1979, 1981), which showed parallel displacement of $1,2,6,7\left[{ }^{3} \mathrm{H}\right]$ progesterone when introduced into an RIA for progesterone over the range $0 \cdot 25-16 \mathrm{nmol} / \mathrm{ml}$. Steroid production by $\mathrm{Y} 1$ cells was therefore measured using a progesterone RIA (Sauer et al. 1986), but using 20 $\alpha$ hydroxyprogesterone to construct standard curves.

\section{Immunodetection of proteins}

PP immunoreactivities were detected in Y1 cell extracts by polyacrylamide gel electrophoresis and immunoblot analysis as described for primary luteal and adrenal cells (Ford et al. 1996, Sayed et al. 1997). For detection of StAR immunoreactivities, mitochondria-enriched fractions were prepared by differential centrifugation. Y1 cells were homogenised $\left(4^{\circ} \mathrm{C}\right)$ in a buffer containing $250 \mathrm{mM}$ sucrose, $10 \mathrm{mM}$ Tris, $0 \cdot 1 \mathrm{mM}$ EDTA, $\mathrm{pH} 7 \cdot 4$. The homogenate was centrifuged $\left(4^{\circ} \mathrm{C}, 600 \mathrm{~g}, 30 \mathrm{~min}\right)$, the pellet was discarded, and the supernatant was recentrifuged $\left(4{ }^{\circ} \mathrm{C}, 10000 \mathrm{~g}, 30 \mathrm{~min}\right)$ to produce a mitochondria-enriched pellet, which was resuspended in a buffer containing $20 \mathrm{mM}$ Tris, $2 \mathrm{mM}$ EDTA, $0.5 \mathrm{mM}$ EGTA, $1 \mathrm{mM}$ phenylmethylsulphonyl fluoride (PMSF), $50 \mu \mathrm{g} / \mathrm{ml}$ leupeptin, $0 \cdot 1 \%(\mathrm{v} / \mathrm{v}) \beta$-mercaptoethanol, $\mathrm{pH} 7 \cdot 4$, and dispersed by sonication. Total protein in extracts was measured using the Bradford assay (Bradford 1976), and mitochondrial fractions contained $9 \pm 1 \%(n=6)$ of total homogenate protein. In some experiments, immunoreactivity was quantified using densitometric scanning (UVP Easy system) of the ECL signal on the film, as described by Parker et al. (1996).

\section{Data analysis}

Differences between means were assessed using one way analysis of variance and Bonferroni's multiple comparisons test, as appropriate, and were considered significant when $P<0 \cdot 05$.

\section{RESULTS}

\section{Stimulation of StAR protein accumulation and steroidogenesis}

Under basal conditions, little StAR immunoreactivity was detected in mitochondria-enriched fractions prepared from Y1 cells, confirming that there is 

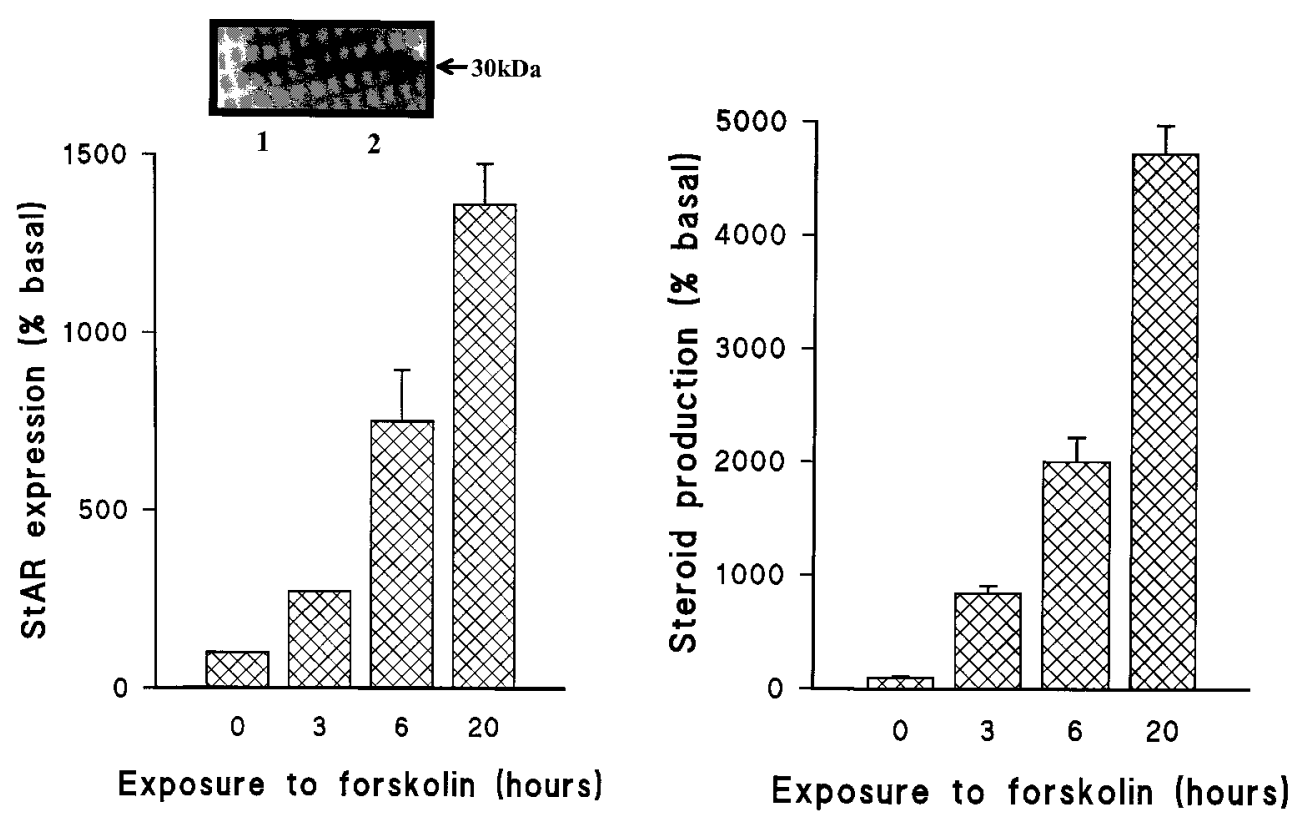

FIGURE 1. Forskolin-induced StAR protein expression and steroidogenesis in Y1 cells. (Left panel) Immunoreactive StAR protein in extracts of Y1 cells after exposure to forskolin $(1 \mu \mathrm{M})$ for various times was quantified by densitometric scanning and expressed as a percentage of the immunoreactivity in control extracts (no forskolin) from the same experiments. Bars show means +s.E.M., $n=3-6$ separate experiments, except 3-h exposure to forskolin where $n=1$. The inset panel shows a representative immunoblot of StAR expression after 20 -h exposure to $1 \mu \mathrm{M}$ forskolin (lane 2), compared with untreated Y1 cells (lane 1). (Right panel) Steroid production by Y1 cells incubated in the presence of forskolin is expressed as a percentage of the production rate in the absence of forskolin $(13 \cdot 5 \pm 0 \cdot 5$ pmoles $/ 10^{6}$ cells/h). Bars show means +s.E.M., $n=8$.

minimal expression of the StAR protein under unstimulated conditions (Clark et al. 1995a). However, a $30 \mathrm{kDa}$ protein with StAR immunoreactivity was detected in extracts of $\mathrm{Y} 1$ cells which had been exposed to the adenylate cyclase activator, forskolin $(1 \mu \mathrm{M})$, as shown in the immunoblot inset in Fig. 1. Figure 1 (left panel) shows the cumulative results from a number of experiments demonstrating that forskolin-induced increases in StAR immunoreactivity were time-dependent, with enhanced accumulation of the $30 \mathrm{kDa}$ StAR being seen after $3 \mathrm{~h}$ and increasing further after 6 and $20 \mathrm{~h}$ exposure to forskolin (Fig. 1, left panel). In parallel experiments, steroid production by $\mathrm{Y} 1$ cells was also stimulated by exposure to $1 \mu \mathrm{M}$ forskolin (Fig. 1, right panel). Enhanced steroidogenesis was detected after $3 \mathrm{~h}$, and enhanced steroid production was maintained for up to $20 \mathrm{~h}$ incubation in the presence of forskolin (Fig. 1).

\section{Expression of phosphoprotein phosphatases in Y1 cells}

Figure 2 shows immunoblots of PP1, PP2A and $\mathrm{PP} 2 \mathrm{~B}$ immunoreactivities in $\mathrm{Y} 1$ cell extracts. $\mathrm{Y} 1$ cell
PP1 migrated on electrophoresis on $15 \%$ polyacrylamide gels with an apparent molecular mass of $37 \mathrm{kDa}$, and PP2A and PP2B migrated with apparent molecular masses of $36 \mathrm{kDa}$ and $16 \mathrm{kDa}$ respectively, in good agreement with the reported sizes of these enzymes in primary steroidogenic tissue (Ford et al. 1996, Sayed et al. 1997).

\section{Effects of inhibitors of PP1/2A on steroidogenesis and StAR protein accumulation in $\mathrm{Y} 1$ cells}

The PP1 and PP2A inhibitors Cal A (1-100 nM) or OA $(10 \mathrm{nM}-1 \mu \mathrm{M})$ produced a concentrationdependent inhibition of forskolin-induced steroid production by $\mathrm{Y} 1$ cells during a $6-\mathrm{h}$ incubation, as shown in Fig. 3. These concentrations of the inhibitors had no effect on unstimulated steroid production by $\mathrm{Y} 1$ cells over a $6-\mathrm{h}$ incubation $(\mathrm{Cal} \mathrm{A}$ $100 \mathrm{nM}, 101 \pm 3 \%$ control; OA $1 \mu \mathrm{M}, 103 \pm 3 \%$, $n=6, P>0 \cdot 2)$. The StAR immunoblot inset into Fig. 4 demonstrates that inhibition of steroidogenesis was accompanied by an inhibition of forskolininduced expression of the $30 \mathrm{kDa}$ StAR protein. This was a reproducible observation, as shown in 


\section{PP1 PP2A PP2B}

\section{$37 \mathrm{kDa} \rightarrow \infty-436 \mathrm{kDa}$}

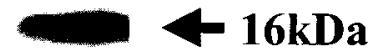

FIGURE 2. PP expression in Y1 cells. The figure shows immunoblots for PP1, PP2A and PP2B in Y1 cell extracts. Molecular masses were calculated from the migration positions of chromophore-tagged proteins of known molecular masses.

Fig. 4, in which $10 \mathrm{nM}$ Cal A markedly reduced forskolin-stimulated accumulation of the StAR protein in three separate experiments, although Cal A alone was without effect on StAR accumulation in Y1 cells (Fig. 4). In a similar experiment, OA $(0 \cdot 1 \mu \mathrm{M})$ completely blocked the forskolin-induced $(1 \mu \mathrm{M})$ increase in StAR expression.

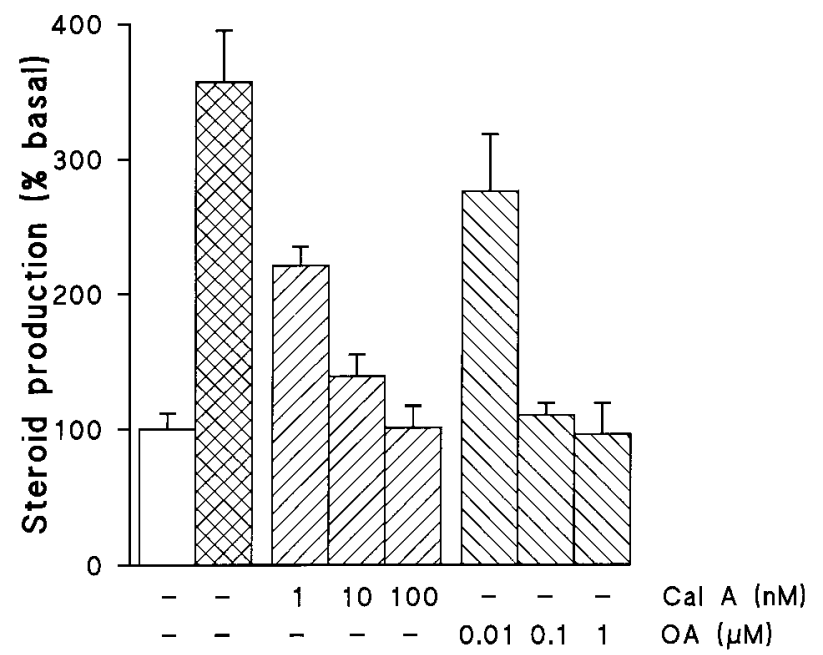

FIGURE 3. Effects of PP1 and PP2A inhibitors on forskolin-induced steroidogenesis. Steroid production by Y1 cells is expressed as a percentage of the basal production in the absence of forskolin, $\mathrm{Cal} \mathrm{A}$ and $\mathrm{OA}$ (213 pmoles $/ 10^{6}$ cells/h, open bar). Forskolin $(1 \mu \mathrm{M}$; cross-hatched bar) significantly stimulated steroid production over basal levels $(P<0 \cdot 01)$. The presence of 1-100 nM Cal A (forward hatching) or $100 \mathrm{nM}-1 \mu \mathrm{M}$ OA (backward hatching) significantly inhibited forskolin-induced steroid production $(P<0 \cdot 01)$. Bars show means + S.E.M., $n=6$.

\section{Effects of inhibitors of PP1/2A on Y1 cell function}

The inhibition of steroidogenesis and of StAR protein expression by PP1/2A inhibitors was not due to cytotoxic effects of these compounds on the Y1 cells in incubations of up to 6-h duration. Estimation of plasma membrane integrity by Trypan blue exclusion showed $>95 \%$ of cells excluding the dye in controls and no detectable differences in cells incubated for up to $6 \mathrm{~h}$ in the presence of forskolin $(1 \mu \mathrm{M})$, Cal A (up to $100 \mathrm{nM}$ ), or OA (up to $1 \mu \mathrm{M}$ ). Similarly, the inhibitors did not affect Y1 cell dehydrogenase activities, even when used at 10-fold higher concentrations than those required to suppress StAR protein expression $(\mathrm{Cal}$ A $100 \mathrm{nM}, 6 \mathrm{~h}$, $110 \pm 14 \%$ control; OA $1 \mu \mathrm{M}, 6 \mathrm{~h}, 110 \pm 7 \%, n=3$, $P>0 \cdot 2)$. The reduction in StAR immunoreactivity in response to inhibition of $\mathrm{PP} 1 / 2 \mathrm{~A}$ activities (see Fig. 4) was selective for the StAR protein since re-probing the immunoblots with an anti-actin antibody showed no significant changes in actin immunoreactivity after a $6-\mathrm{h}$ incubation in the presence of Cal A $(+10 \mu \mathrm{M}$ forskolin, $113 \pm 18 \%$ control; $+10 \mu \mathrm{M}$ forskolin $+10 \mathrm{nM} \mathrm{Cal} \mathrm{A,} 107 \pm 24 \%, n=5$, $P>0 \cdot 2$ vs control for both treatments). The effects of PP1/2A inhibitors on forskolin-induced steroidogenesis were not due to direct inhibition of the steroidogenic enzymes in $\mathrm{Y} 1$ cells, since $\mathrm{Cal} \mathrm{A}$ did not inhibit steroid production from Y1 cells supplied with $22 \mathrm{ROHC}$ or pregnenolone, both of which enter the steroidogenic pathway after cholesterol transport to the inner mitochondrial membrane, as shown in Table 1. In these experiments forskolin $(1 \mu \mathrm{M})$, $22 \mathrm{ROHC}(5 \mu \mathrm{M})$ and pregnenolone $(5 \mu \mathrm{M})$ all produced significant increases in steroid production by 


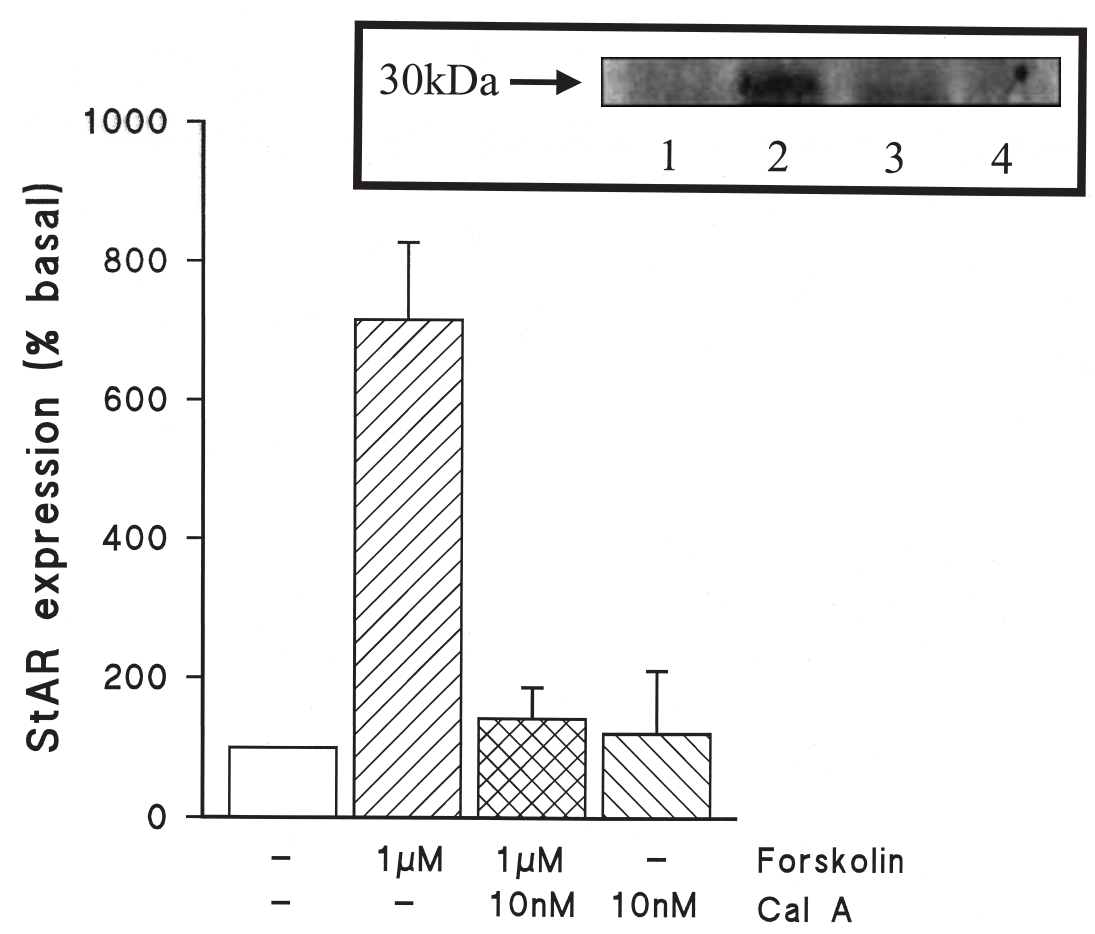

FIGURE 4. Inhibition of StAR protein accumulation in Y1 cells. StAR protein immunoreactivity was quantified by densitometry and expressed as a percentage of expression in unstimulated controls. Incubation in the presence of forskolin $(1 \mu \mathrm{M})$ for $6 \mathrm{~h}$ caused a marked increase in StAR immunoreactivity in mitochondria-enriched fractions, and the presence of Cal A $(10 \mathrm{nM})$ significantly reduced forskolin-induced StAR accumulation $(P<0 \cdot 05)$. Exposure of Y1 cells to Cal A alone did not affect StAR expression. Data are means+s.E.M. from three separate experiments. The inset panel shows a representative immunoblot from an experiment in which StAR immunoreactivity was measured after 6 -h incubation in normal medium (lane 1), or in medium supplemented with $1 \mu \mathrm{M}$ forskolin (lane 2 ), $1 \mu \mathrm{M}$ forskolin plus $10 \mathrm{nM}$ Cal A (lane 3), or $10 \mathrm{nM}$ Cal A alone (lane 4). The molecular mass of StaR immunoreactivity was calculated from the migration positions of chromophore-tagged proteins of known molecular masses.

Y1 cells during a 6-h incubation. Cal A (3-30 nM) completely inhibited forskolin-stimulated steroid production, but had no significant effect on steroid production induced by $22 \mathrm{ROHC}$ or pregnenolone (Table 1).

\section{DISCUSSION}

The Y1 mouse adrenal cell line offered a useful experimental model for the present studies. StAR protein is not abundant in steroidogenic tissues, so an in vitro cell line provides large amounts of tissue from which to prepare mitochondria-enriched fractions, whilst avoiding the use of large numbers of experimental animals. Although Y1 cells have a reduced capacity for 21-hydroxylation and 11hydroxylation reactions, the earlier parts of the biosynthetic pathway from cholesterol to pregnenolone are intact, and the PKA-dependent signalling pathways are thought to reflect those in primary

www.endocrinology.org adrenal cells (Schimmer 1979, 1981). We have now shown that Y1 cells express immunoreactive PP1, PP2A and PP2B of molecular masses similar to those reported in primary adrenal cells (Sayed et al. 1997), and that two structurally dissimilar inhibitors of PP1 and PP2A cause a concentration-dependent inhibition of steroid production in $\mathrm{Y} 1$ cells, in accordance with their effects in primary tissues (Abayasekara et al. 1996, Sayed et al. 1997).

In the present study, forskolin stimulated the accumulation of the $30 \mathrm{kDa}$ StAR protein in Y1 cell mitochondria and increased steroid synthesis over time-courses similar to those reported for other steroid-producing cells (Clark et al. 1995a,b), in accordance with the StAR protein being required for cholesterol transport and steroid synthesis, suggesting that $\mathrm{Y} 1$ cells are similar to primary adrenal tissue and to other steroidogenic cells in this respect (Stocco 1997, 1998). The enhanced rate of steroid production by $\mathrm{Y} 1$ cells was maintained for up to $20 \mathrm{~h}$, and the increased accumulation of the 
TABLE 1. Effects of calyculin A on 22R-hydroxycholestrol- and pregnenolone-induced steroid production in Y1 cells. Y1 cells were incubated for $6 \mathrm{~h}$ in the absence or presence of $1 \mu \mathrm{M}$ forskolin, $5 \mu \mathrm{M} 22 \mathrm{R}$-hydroxy cholesterol (22ROHC) or $5 \mu \mathrm{M}$ pregnenolone and in the absence or presence of 3-30 $\mathrm{nM}$ Cal A as shown, and steroid production was determined as described in the Methods section. Data are means \pm s.E.M.

\begin{tabular}{|c|c|c|c|c|}
\hline & \multicolumn{4}{|c|}{ Steroid production $\left(\mathrm{pmol} / 10^{5}\right.$ cells $\left./ \mathrm{h}\right)$} \\
\hline & $0 \mathrm{Cal} \mathrm{A}$ & 3 nM Cal A & $10 \mathrm{nM} \mathrm{Cal} \mathrm{A}$ & 30 nM Cal A \\
\hline \multicolumn{5}{|l|}{ Treatment } \\
\hline Control & $17 \cdot 4 \pm 6 \cdot 3$ & $17 \cdot 3 \pm 3 \cdot 3$ & $20 \cdot 3 \pm 3 \cdot 2$ & $22 \cdot 7 \pm 2 \cdot 8$ \\
\hline Forskolin $(1 \mu \mathrm{M})$ & $75 \cdot 9 \pm 6 \cdot 6$ & $24 \cdot 3 \pm 2 \cdot 3 *$ & $14 \cdot 1 \pm 1 \cdot 9 *$ & $11 \cdot 7 \pm 2 \cdot 4 *$ \\
\hline $22 \mathrm{ROHC}(5 \mu \mathrm{M})$ & $62 \cdot 9 \pm 4 \cdot 9$ & $69 \cdot 9 \pm 2 \cdot 2$ & $57 \cdot 2 \pm 5 \cdot 6$ & $71 \cdot 9 \pm 7 \cdot 8$ \\
\hline Pregnenolone $(5 \mu \mathrm{M})$ & $68 \cdot 5 \pm 17 \cdot 1$ & $55 \cdot 3 \pm 9 \cdot 9$ & $68 \cdot 4 \pm 5 \cdot 4$ & $90 \cdot 1 \pm 9 \cdot 1$ \\
\hline
\end{tabular}

$30 \mathrm{kDa}$ StAR protein in mitochondria over this time is consistent with the accumulation of a $30 \mathrm{kDA}$ product from a cytosolic active $37 \mathrm{kDa}$ precursor involved in mitochondrial cholesterol transport (see Stocco \& Clark 1996, Stocco 1997, 1998). Our measurements of immunoreactive StAR protein also demonstrated unequivocally that inhibitors of PP1 and $\mathrm{PP} 2 \mathrm{~A}$ inhibited both steroid production and the accumulation of the $30 \mathrm{kDa}$ StAR protein in $\mathrm{Y} 1$ cells. Since the inhibitors had no generalized cytotoxic effects on Y1 cells when used over the time-course and concentration range of the present studies, the simplest explanation for these observations is that inhibiting PP1 and PP2A activities blocks PKA-induced steroid production primarily through preventing the increased expression of StAR protein.

These novel results have several implications for the regulation of steroid production. First, our observations imply that PP1 and/or PP2A activities are essential for the PKA-dependent increases in the expression of StAR protein which precede enhanced steroid production in many steroidogenic tissues. This absolute requirement for a dephosphorylation process in addition to PKA-dependent phosphorylation events suggests the involvement of a cyclic rather than a linear transduction process, the precise nature of which is unknown at present. Secondly, the coupling of an inhibition of StAR protein expression to an inhibition of steroid production lends further support to the notion that StAR protein is the rate-limiting factor in steroidogenesis, and complements previous studies in which expression of StAR protein has been linked to increased steroid production (see Stocco \& Clark 1996 for review). Thirdly, StAR protein is itself a potential substrate for protein kinases and PPs as it contains consensus sites for PKA-dependent phosphorylation, and its phosphorylation state may influence its action in promoting steroid production (Stocco 1998). The realization that manipulating the phosphorylation/dephosphorylation cycle in steroidogenic cells may influence the expression of StAR protein, as well as its function once expressed, will be important for the design of future studies into the function of StAR protein in situ. Finally, the identification of PP1/2A activities as being crucial for the maintenance of stimulated steroidogenesis through StAR protein expression may offer potential for therapeutic manipulation of steroid production by pharmacological modification of PP activities.

\section{ACKNOWLEDGEMENTS}

This work was supported by the Medical Research Council (MRC), the Biotechnology and Biological Sciences Research Council (BBSRC) and the Wellcome Trust (grant code $054789 / Z / 98 / Z$ ). S S was an MRC postgraduate student, and $S G$ is a BBSRC postgraduate student. We gratefully acknowledge the generous gift of anti-StAR antibody from Professor Douglas Stocco (Texas-Tech University, TX, USA).

\section{REFERENCES}

Abayasekara DRE, Ford SL, Persaud SJ \& Jones PM 1996 Role of phosphoprotein phosphatases in the corpus luteum. II. Control of progesterone secretion by isolated rat luteal cells. Fournal of Endocrinology 150 213-221. 
Azhar S, Wang H, Tsai L \& Reaven E 1992 Okadaic acid interferes with lipoprotein supported corticosterone production in rat adrenal cells. Biochemical and Biophysical Research Communications 179 726-733.

Azhar S, Frazier JA, Tsai L \& Reaven E 1994 Effect of okadaic acid on utilisation of lipoprotein-derived cholesteryl esters by rat steroidogenic cells. Fournal of Lipid Research $\mathbf{3 5}$ 1161-1176.

Balasubramanian K, Lavoie HA, Garmey JC, Stocco DM \& Veldhuis JD 1997 Regulation of porcine granulosa cell steroidogenic acute regulatory protein (StAR) by insulin-like growth factor-I: synergism with follicle-stimulating hormone or protein kinase A agonist. Endocrinology 138 433-439.

Bradford MM 1976 A rapid and sensitive method for the quantification of microgram quantities of protein utilising the principle of protein-dye binding. Analytical Biochemistry 72 $248-254$

Clark BJ, Wells J, King SR \& Stocco DM 1994 The purification, cloning, and expression of a novel luteinizing hormone-induced mitochondrial protein in MA-10 mouse Leydig tumor cells: characterization of the steroidogenic acute regulatory protein (StAR). Fournal of Biological Chemistry $26928314-28322$.

Clark BJ, Pezzi V, Stocco DM \& Rainey WE 1995a The steroidogenic acute regulatory protein is induced by angiotensin-II and $\mathrm{K}^{+}$in $\mathrm{H} 295 \mathrm{R}$ adrenocortical cells. Molecular and Cellular Endocrinology 115 215-219.

Clark BJ, Soo SC, Caron KM, Ikeda Y, Parker KL \& Stocco DM $1995 b$ Hormonal and developmental regulation of the steroidogenic acute regulatory protein. Molecular Endocrinology 9 1346-1355.

Cohen P 1989 The structure and regulation of protein phosphatases. Annual Review of Biochemistry 58 453-508.

Ford SL, Abayasekara DRE, Persaud SJ \& Jones PM 1996 Role of phosphoprotein phosphatases in the corpus luteum. I. Identification and characterisation of serine/threonine phosphoprotein phosphatases in isolated rat luteal cells. Fournal of Endocrinology 150 205-211.

Kim YC, Ariyoshi N, Artemenko I, Elliott ME, Bhattacharyya KK \& Jefcoate CR 1997 Cytochrome P450scc in rat adrenal cells mediated by regulation of the steroidogenic acute regulatory protein. Steroids $\mathbf{6 2} 10-20$.

Lin D, Sugawara T, Strauss JF, Clark BJ, Stocco DM, Saenger P, Rogol A \& Miller WL 1995 Role of steroidogenic acute regulatory protein in adrenal and gonadal steroidogenesis. Science 267 1828-1831.

Liu ZM \& Stocco DM 1997 Heat shock-induced inhibition of acute steroidogenesis in MA-10 cells is associated with inhibition of the synthesis of the steroidogenic acute regulatory protein. Endocrinology 138 2722-2728.

Liu J, Hekkila P, Kahri A \& Voutilainen R 1996 Expression of the steroidogenic acute regulatory protein in adrenal tumours and adrenal cells. Fournal of Endocrinology 150 43-50.
Nishikawa T, Sasano H, Omura M \& Suematsu S 1996 Regulation of expression of the steroidogenic acute regulatory (StAR) protein by ACTH in bovine adrenal fasciculata cells. Biochemical and Biophysical Research Communications 223 12-18.

Orme-Johnson NR 1990 Distinctive properties of adrenal mitochondria. Biochimica et Biophysica Acta 1020 213-231.

Papadopoulos V, Amri H, Boujrad N, Cascio C, Culty M, Garnier M, Hardwick M, Li H, Vidic B, Brown AS, Reversa JL, Bernassau JM \& Drieu K 1997 Peripheral benzodiazepine receptor in cholesterol transport and steroidogenesis. Steroids 62 21-28.

Parker KJ, Jones PM, Hunton CH, Persaud SJ, Taylor CG \& Howell SL 1996 Identification and localisation of a type IV cytosolic phospholipase A2 in rat pancreatic cells. Fournal of Molecular Endocrinology 17 31-43.

Pescador N, Soumano K, Stocco DM, Price CA \& Murphy BD 1996 Steroidogenic acute regulatory protein in bovine corpora lutea. Biology of Reproduction 55 485-491.

Ramnath HI, Peterson S, Michael AE, Stocco DM \& Cooke BA 1997 Modulation of steroidogenesis by chloride ions in MA-10 mouse tumor Leydig cells: roles of calcium, protein synthesis, and the steroidogenic acute regulatory protein. Endocrinology 138 2308-2314.

Sauer MJ, Foulkes JA, Worsfold \& Morris BA 1986 Use of progesterone 11-glucuronide-alkaline phosphatase conjugate in a sensitive micro-titre-plate enzyme immunoassay of progesterone in milk and its application to pregnancy in dairy cattle. Fournal of Reproduction and Fertility $\mathbf{7 6}$ 375-391.

Sayed SB, Whitehouse BJ \& Jones PM 1997 Phosphoserinethreonine phosphatases in the rat adrenal cortex: a role in the control of steroidogenesis? Fournal of Endocrinology 154 449-458.

Schimmer BP 1979 Adrenocortical Y1 cells. Methods in Enzymology 58 570-574.

Schimmer BP 1981 The adrenocortical tumour cell line, Y1. In Functionally Differentiated Cell Lines, pp 61-92. Ed. G Sato. New York: Alan R Liss, Inc.

Schimmer BP 1995 The 1994 Upjohn Award Lecture. Molecular and genetic approaches to the study of signal-transduction in the adrenal cortex. Canadian Fournal of Physiology and Pharmacology 73 1097-1107.

Stocco DM 1997 The steroidogenic acute regulatory (StAR) protein two years later - an update. Endocrine 6 99-109.

Stocco DM 1998 Recent advances in the role of StAR. Reviews of Reproduction 3 82-85.

Stocco DM \& Clark BJ 1996 Regulation of the acute production of steroids in steroidogenic cells. Endocrine Reviews 17 221-244.

RECEIVED 19 October 1999 